BIBLIOGRAPHIC REVIEW

\title{
The treatment of gummy smile: integrative review of literature
}

\author{
Dayanne Moura', Emanuelle Lima', Ruthinéia Lins², Rodrigo Souza², Ana Martins², Bruno Gurgel².
}

\begin{abstract}
1. DDs, MSc Student, Public Health in Dentistry, Federal University of Rio Grande do Norte, Department of Dentistry Natal/RN, Brazil

2. Adjunct Professor, Federal University of Rio Grande do Norte (UFRN), Department of Dentistry, Natal/RN, Brazil.
\end{abstract}

Correspondence to: DDs, MSc Student, Dayanne Monielle Duarte Moura, Federal University of Rio Grande do Norte, Department of Dentistry, Av. Salgado Filho, 1787, Lagoa Nova, Natal / RN. CEP: 59056-000. Tel: +55(84)98196017. e-mail: d.monielle@hotmail.com

Trabajo recibido el 04/03/2016. Aprobado para su publicación el 20/10/2016

\begin{abstract}
The use of periodontal surgery to treat the condition of gummy smile is an essentially aesthetic approach and plays an important role in raising the self-esteem of patients. Effective treatment requires identification of the best technique for the correction, and the long-term predictability of the procedure. Objective: The aim of this study was to conduct an integrative review of scientific evidence relating to the periodontal surgery techniques used to treat gummy smile. Method and Materials: According to the inclusion and exclusion criteria A total of five (05) articles from the PubMed, Scopus and Web of Science databases were analyzed. The majority of cases found featured women, and the average age was 26 years. In most cases, the predominant surgical technique was based on the use of gingivectomy with osteotomy, with a follow-up period of around 6 months. Conclusion: This review revealed a serious lack of controlled and randomized clinical studies into the use of periodontal surgery to treat gummy smiles and highlighted a need for longitudinal clinical studies, with greater evidence, about the best type of periodontal surgery for this purpose. KEY-WORDS Smiling; Gingiva; Esthetics Dental; Surgery.
\end{abstract}

Rev. Clin. Periodoncia Implantol. Rehabil. Oral Vol. 10(1); 26-28, 2017.

\section{INTRODUCTION}

The main common purpose of the various types of dental specialty is based around the restoration of the health and aesthetic and masticatory function of a patient. Today, however, people often seek dental treatment for aesthetic reasons, forcing professionals to find ways of achieving more harmonious and symmetrical smiles, in order to ensure satisfactory rehabilitation. ${ }^{1,2}$

Factors normally involved in the aesthetic consideration of a smile are related to the lips, positioning, size, shape, and teeth color, as well as the proximity between the gingival tissue and the teeth. ${ }^{3,4}$ Other factors associated with aesthetics are related to health, tooth discoloration, morphology and suitable gingival contours, all of which are considered essential to an attractive smile. ${ }^{5}$ Among the many disorders that can compromise the aesthetics of a smile are gingival excess or exacerbated gingival display, a medical condition known as gummy smile. ${ }^{6}$

Gummy smile is recognized by the American Academy of Periodontology (AAP) as a deformity and mucogingival condition that affects the area around the teeth. ${ }^{7}$ Allen (1998) stated that gum exposure of less than 2-3 $\mathrm{mm}$ can be considered attractive, with overexposure (> $3 \mathrm{~mm}$ ) generally considered unattractive and known as gummy smile, which is usually considered an aesthetic problem..$^{8,9}$ However, perception of excessive gingival display is also subject to cultural and ethnic preferences. In some European countries gingival display of up to $4 \mathrm{~mm}$ or more is acceptable, while exposure greater than $2-3 \mathrm{~mm}$ is considered unsightly in the USA. ${ }^{7}$

The main etiological factors related to gummy smile involve gingival (altered passive eruption), skeletal (vertical maxillary excess) and muscle (upper lip hyperfunction) characteristics. ${ }^{11}$ Altered passive eruption occurs when the periodontal complex does not migrate apically in the direction of the cementoenamel junction, covering part of the clinical crown, resulting in short teeth. ${ }^{10}$ This covering may have aesthetic complications, especially in patients with a high smile line. The prevalence of gummy smile is $10 \%$ among the population aged between 20 and 30 years, and is more common among women than men ${ }^{11}$.

Some consequences of this change are the short clinical crown and excess of gingival tissue ${ }^{12}$. For the diagnosis and planning of the altered passive eruption, some authors suggest the association of radiographic analysis ${ }^{13,14}$, transgingival probe measurement ${ }^{15}$ and more recently, the use of cone beam computed tomography ${ }^{16}$. The therapeutic procedure will depend on the etiology and the seriousness of the case that can indicate the removal of excess and remodeling of gingival tissues ${ }^{17}$. The gingivectomy procedure is indicated when there is the need of remodeling of gingival tissues only, when the elements are with their crown partially open. When the bone level is adjacent to the cemento-enamel junction or even covering it, the gingivectomy is performed along with the osteotomy.

In these cases, surgical techniques to lengthen the clinical crown can effectively resolve aesthetic problems. ${ }^{18}$ Other recommended treatment procedures are apically positioned flaps, orthodontics, dentistry, orthognathic surgery, myotomies and even the use of botulinum toxin. ${ }^{13}$ Lengthening the clinical crown involves removing a strip of gum tissue with or without bone resectioning. ${ }^{11}$ It is considered a common technique for the restoration of periodontal space in case of caries and fractures, as well as for the correction of aesthetic disorders. ${ }^{20}$

The aim of this study was therefore to conduct an integrative review of scientific evidence relating to the periodontal surgery techniques used to treat gummy smile.

\section{METHODOLOGY}

An integrative literature review was performed to analyze and evaluate existing scientific knowledge of the subject. The bibliographic search was performed in the first semester of 2015, in the PubMed, Scopus and Web of Science databases, in addition to a manual search of articles cited in the studies selected for the review.

The following search strategy was used: ((smiling OR gummy smile) AND (treatment) AND (gingivoplasty OR gingivectomy OR crown lengthening) AND (esthetics OR surgery, plastic)). This strategy was based on DeCS (Health Science Descriptors) indexed descriptors and the main terms found in a reading of a number of relevant articles prior to the study. The search was performed by two independent examiners. In case of disagreement, the reviewers met to discuss the inclusion or exclusion of the article.

Scientific articles on aesthetic periodontal surgery in English, published on any date, and which were controlled and/or randomized clinical studies, prospective cohort studies, case series or case reports were included in the study. Studies in Portuguese and Spanish that involved other types of surgery (orthognathic surgery, myotomies, or lip repositioning) or non-surgical treatments (orthodontics, dentistry, botulinum toxin), or were literature reviews or appeared as not complete in the database were excluded. Studies not available in the databases were requested by direct contact with the author or by purchasing the magazine. Duplicate articles were considered only once.

Following initial selection based on titles and abstracts, the full 
texts were read, and information relating to the following variables was gathered: authors, year, objectives, methodological characteristics of the study, sample (age, gender, number of participants), surgical technique, follow-up period, main results and conclusions.

\section{RESULTS}

The results found in the databases searched are shown in the flowchart in Figure 1.

A total of 69 references were found in the PubMed database. Following analysis based on the inclusion criteria and reading of the available abstracts, 12 articles were selected. Nine references were found in the Scopus database, and three articles were selected using the same criteria. Seven references were found in the Web of Science database, with only one item included after the inclusion and exclusion criteria were applied.

Of the articles analyzed in full, two case reports, two case series and one randomized controlled trial of the subject were found. These were published between 2008 and 2014

The average age of patients undergoing surgery for gummy smile correction was 26 years. A total of 48 patients undergoing surgery and follow-up monitoring by researchers were included in the studies, of whom 37 were women and 11 were men. The predominant surgical technique was based on the use of gingivectomy with osteotomy, with follow-up times of two months ${ }^{21}$, six months ${ }^{22-24}$ or 12 months (one study only) ${ }^{18}$. The main findings relate to patient satisfaction after surgery. In al cases the patients were satisfied with the cosmetic results. There was no difference between surgical techniques in studies that compared the two ${ }^{18,21}$. (Table 1)

Figure I. Flowchart of publications in all databases

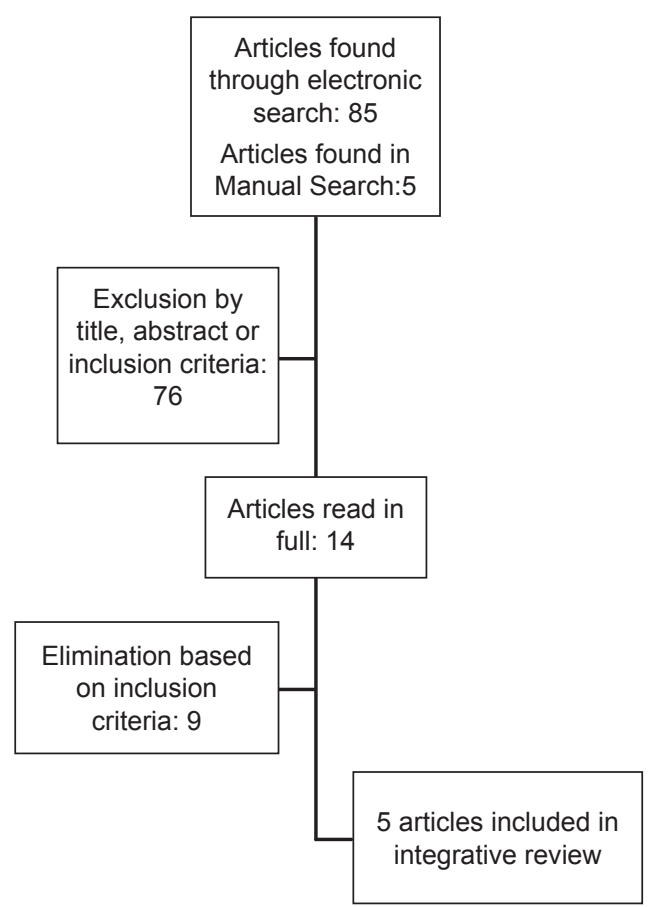

\section{DISCUSSION}

Meeting the expectations of patients seeking cosmetic treatments has become a challenging goal, especially when such expectations are based on aesthetic standards. ${ }^{7}$ For gummy smile correction, surgical techniques that lengthen the clinical crown, such as gingivectomy or an apical flap positioning, with and without bone resection, ${ }^{3}$ are usually recommended. Although this is a prevalent, highly publicized medical condition, few clinical studies are available on the subject.

Even with the scant of scientific evidence it inferable that the available literature gives rise to the indication of the gingivectomy procedure when there is only the need of remodeling gingival tissues, with the exposa of the anatomical crown of teeth which is partially covered by gingival tissue. In cases where the bone level is coincident with the cementoenamel junction, or covering it, it becomes necessary the association of complementary osteotomy to restore the biological space, so that it can allow the adaptation of periodontal structures, whether they are junctional epithelium or connective tissue attachment. In these situations, it is necessary to emphasize the importance of the periodontal biotype for determining the quantity of osteotomy to be performed. It has been recommended a distance of $2 \mathrm{~mm}$ between the cemento-enamel junction and the crest bone in patients with thin biotype, and a distance of $3 \mathrm{~mm}$ in cases of thick periodontal biotype ${ }^{25}$. The diagnosis and measurement of bone level relative to the cemento-enamel junction must be performed by transgingival probing with anesthetized patients and confirmed after the retail survey and direct access to bone tissue ${ }^{15}$

In terms of the methodological design of the included studies, most were case reports, case series or literature reviews, even though such studies are not recommended when seeking scientific evidence. There were no clinically controlled, randomized multi-studies that evaluated clinical crown lengthening procedures for the treatment of a gummy smile. One recently published, controlled, randomized clinical scientifically relevant study ${ }^{12}$ was found, which compared the use of two periodontal surgical techniques in the same patient from a surgical point of view. This shows how surprisingly little literature there is regarding periodontal surgery for the treatment of gummy smile.

Due to the difficulty in finding clinical studies that address this issue and effectively prove the effectiveness or ineffectiveness of a certain technique, data was collected from case reports, case series, and clinical trials. Various narrative literature reviews were found using the search strategy, but were excluded from this study because they are even less based on scientific evidence and so are less suited to answering our original question. In terms of the average age of patients undergoing periodontal surgery, young adults were prevalent in the studies found. This may be related to the aesthetic needs of individuals at this age and the fact that the gummy smile condition tends to gradually decrease with age as a result of upper and lower lip mobility, which in turn leads to a decrease in the exposure of the upper incisors in older patients. ${ }^{5}$

There was a prevalence of women in all the studies analyzed, due to the fact that a gummy smile is most commonly found in the female gender ${ }^{5}$. The largest number of surgically treated cases was among women, perhaps due to a greater aesthetic need among females, especially with regard to an attractive smile.

The main surgical technique chosen to lengthen the clinical crown was gingivectomy, with or without bone resection. These surgical procedures often require time and the use of sutures, and can cause postoperative morbidity for the patient. ${ }^{18}$ The personal satisfaction of the patient after treatment should therefore be one of the requirements for the success of the technique. A controlled randomized clinical study ${ }^{12}$ used the technique of gingivectomy with osteotomy, both open flap and flapless, in the same patient and obtained positive results during an evaluation period of 12 months for both techniques, showing that minimally invasive procedures can also be used to surgically treat a gummy smile.

Researches still add that the lengthening of the clinical crown and subsequent osteotomy/osteoplasty are also a part of the "gummy smile" treatment ${ }^{19}$. Ribeiro et al. (2014) emphasize that in cases of altered passive eruption, it is necessary the application of the osteoplastic technique to regularize the bone in the anterior maxilla. This procedure, in addition to the improvement of aesthetics, allows a better adaptation of the superior lip. Other authors ${ }^{18}$ also recommend the increase of the clinical crown at the anterior superior sextant, through osteotomy and osteoplasty, to correct the altered passive eruption. In periodontal plastic surgeries, it is also recommended the use of the gingivectomy technique or flap repositioned apically technique to alter the conformation of soft tissues that contour the teeth, as well as its relative proportion ${ }^{27}$. Gingivectomy must be performed in the presence of inserted mucosa, enough keratinized that after the removal of the gingival tissue, there is still keratinized mucosa. When there is little keratinized mucosa, about 2 to $3 \mathrm{~mm}$, priority should be given to maintaining the $\mathrm{MC}$ and, therefore, the retail shifted apically is chosen.

The follow-up periods of the surgical cases treated were 3,6 and 12 months. These are relatively short follow-up times, which may undermine the predictability of the outcome, which provides guidance to the medical professional and patients with respect to the recurrence and/or appearance of any problems that may occur over the passage of time, such as gingival recession. However, no studies were found that observe tissue change and aesthetic factors after clinical crown lengthening operations. ${ }^{12}$

The absence of long follow-up periods can also impair the reliability of the results obtained and conclusions drawn. It would be ideal to follow cases for a considerably longer period, in order to affirm the success of the surgical techniques used. Another limitation of the conclusions is that the majority of the types of study found were reports and case series with small samples, and results based on subjective patient satisfaction, which did not compare the quality of the surgical techniques used. 
Table I. Description of the articles included for Integrative Review by Authors, Year, Study Design, Surgical Technique, Follow-up Period and Main Results

\begin{tabular}{|c|c|c|c|c|c|}
\hline Authors and year & $\begin{array}{l}\text { Type of } \\
\text { Study }\end{array}$ & Sample & $\begin{array}{l}\text { Surgical } \\
\text { Technique }\end{array}$ & Follow-up & Results \\
\hline Rossi, R. et al. 2008 & $\begin{array}{l}\text { Clinical Case } \\
\text { Reports }\end{array}$ & 2 patients & $\begin{array}{l}\text { Open flap } \\
\text { gingivectomy with } \\
\text { bone resection }\end{array}$ & 6 months. & $\begin{array}{l}\text { Patients were satisfied with the treatment. } \\
\text { The smile line and quantity of soft tissue } \\
\text { were aesthetically pleasing after six months. }\end{array}$ \\
\hline Cairo, F. et al. 2012 & Case Series & 11 patients & $\begin{array}{l}\text { Open flap } \\
\text { gingivectomy with } \\
\text { bone resection }\end{array}$ & 6 months & $\begin{array}{l}\text { All patients were satisfied with the final } \\
\text { clinical results. }\end{array}$ \\
\hline Narayan,S. et al 2011 & $\begin{array}{l}\text { Clinical Case } \\
\text { Reports }\end{array}$ & 2 patients & $\begin{array}{l}\text { Gingivectomy with } \\
\text { and without bone } \\
\text { resection }\end{array}$ & 2 months & $\begin{array}{l}\text { Both techniques demonstrated good } \\
\text { aesthetic results. }\end{array}$ \\
\hline Ribeiro, FV et al. 2014 & $\begin{array}{l}\text { Randomized } \\
\text { controlled } \\
\text { clinical trial }\end{array}$ & 28 patients & $\begin{array}{l}\text { Gingivectomy with } \\
\text { and without open } \\
\text { flap }\end{array}$ & 12 months & $\begin{array}{l}\text { There was no significant difference between } \\
\text { the techniques for the criteria evaluated: } \\
\text { Visible plaque index, Bleeding on probing } \\
\text { index, Relative position of gingival margin, } \\
\text { Relative Clinical Insertion Level, Probing } \\
\text { Depth, Bleeding on Probing, height of } \\
\text { keratinized gingiva. The patient's perception } \\
\text { and aesthetic appearance were also } \\
\text { evaluated and the results were similar for } \\
\text { both techniques. }\end{array}$ \\
\hline $\begin{array}{l}\text { Dharsiyani, K. et al. } \\
2014\end{array}$ & Case series & 5 patients & $\begin{array}{l}\text { Gingivectomy with } \\
\text { and without bone } \\
\text { resection }\end{array}$ & 6 months & $\begin{array}{l}\text { In all the elements undergoing surgery the } \\
\text { clinical crown was lengthened. At the end of } \\
\text { six months, there was a gain in crown length } \\
\text { of about } 2 \mathrm{~mm} \text { per tooth. }\end{array}$ \\
\hline
\end{tabular}

A gummy smile has a major impact on the relationships, self-esteem and attractiveness of patients. Its correction therefore improves both the aesthetics and confidence of the patient. In all the studies evaluated, there was great satisfaction with regard to the patient's smile after treatment, regardless of the technique and follow-up period.

There is a significant lack of controlled and randomized clinical studies addressing the treatment of gummy smile with periodontal surgery. It was considerably more difficult to find such studies than studies relating to nonsurgical therapeutic approaches, such as botulinum toxin, which appeared more frequently in the database search.

\section{CONCLUSIONS}

Based on the results of the studies found, the most frequently used technique was gingivectomy with osteotomy, which demonstrated favorable results, both from an aesthetic and patient satisfaction perspective.

\section{CONFLICT OF INTEREST}

The authors declare that there is no conflict of interest regarding the publication of this article.

\section{References}

1. Magne $\mathrm{P}$, Belser $\mathrm{U}$. Bonded porcelain restorations in the anterior dentition. Carol Stream (IL); Quintessence Int, 2004: 58-64.

2. Alpiste-illueca F. Altered passive eruption (APE): A little-known clinical situation. Med Oral Patol Oral Cir Bucal 2011; 16(1): 100-104

3. Nicholas C. Davis. Smile Design. Dent Clin N Am 51 (2007) 299-318

4. Oliveira MT. Molina GO. Furtado A. Ghizoni JS. Pereira JR. Gummy smile: A contemporary and multidisciplinary overview, Dental Hypotheses Apr-Jun 2013 / Vol 4

5. Sildeberg, N. Goldstein, M. Smidt, A. Excessive gingival display - Etiology, diagnosis, and treatment modalities. Quintessence Int 40:809-818 2009.

6. Coslet JG, Vanarsdall R, Weisgold A. Diagnosis and classification of delayed eruption of the dentogengival junction in the adult. Alpha Omegan 1977; 70(3): 24 28.

7. Armitage, GC. Development of a classification system for periodontal diseases and conditions. Annals of periodontology / the American Academy of Periodontology, 4 (1999), pp. 1-6

8. Abou-Arraj RV, Souccar NM. Periodontal treatment of excessive gingival display. Seminars in Orthodontics, Vol19, N4 (December), 2013:pp267-278.

9. Allen EP. Use of mucogingival surgical procedures to enhance esthetics. Dent Clin North Am 1988; 32:307-30

10. Jananni M. Sivaramakrishnan M. Libby TJ. Surgical correction of excessive gingival display in class I vertical maxillary excess: Mucosal strip technique. Journal of Natural Science, Biology and Medicine | July 2014 | Vol 5 |

11. Tjan AH, Miller GD, The JG. Some esthetic factors in a smile. J ProsthetDent 1984;51:248.

12. Isiksala, E., Hazarb, S., Akyalçınc, S. Smile esthetics: Perception and comparison of treated and untreated smiles. AJO-DO. 2006. 129(1): 8-16.

13. Levine RA., McGuire, M. The diagnosis and treatment of the gummy smile. Europe PMC. 1997. 18(8):757-62.

14. Alpiste-lllueca, F. Dimensions of the Dentogingival Unit in Maxillary Anterior Teeth: A New Exploration Technique (Parallel Profile Radiograph). International Journal of Periodontics \& Restorative Dentistry. 2004, 24 (4): 386-396.

15. De Rouck, T., Eghbali, R., Collys, K., De Bruyn, H., Cosyn, J. The gingival biotype revisited: transparency of the periodontal probe through the gingival margin as a method to discriminate thin from thick gingiva. Journal of clinical Periodontology. 2009. 36(5):428-433.
16. Benninger, B., Peterson, A., Cook, V. Assessing Validity of Actual Tooth Height and Width From Cone Beam Images of Cadavers With Subsequent Dissection to Aid Oral Surgery. Journal of Oral and Maxillofacial Surgery. 70(2): 302-306.

17. Braga, MS., et al. Plastic surgery periodontal for eruption of correction passive amended. Braz J Periodontol. 2015. 25(4).

18. Ribeiro FV, Hirata DY, Reis FA, Santos VR, Miranda TS, Faveri M, et al. OpenFlap Versus Flapless Esthetic Crown Lengthening: 12-Month Clinical Outcomes of a Randomized Controlled Clinical Trial. J Periodontol. 2014, Abril. 85:4.

19. Joly JC, Carvalho PFM, Silva RC. Reconstrução tecidual estética: procedimentos plásticos e regenerativos periodontais e peri-implantares. São Paulo, SP: Artes Medicas, 2010. 693 p.

20. Garber DA, Salama MA. The aesthetic smile: diagnosis and treatment. Periodontol 2000, 1996; 11(6): 18-28.

21. Sarita NTV, Narayan PC. Correction of gummy smile: A report of two cases. J Indian SocPeriodontol. 2011 Oct-Dec; 15(4): 421-424.

22. Roberto R, Remo B, Morales RIS. Treatment of Altered Passive Eruption: Periodontal Plastic Surgery of the Dentogingival Junction. Eur J EsthetDent. 2008; 3(3):212-23.

23. Cairo F, Graziani F, Franchi L, Defraia E, Prato GPP. 'Periodontal Plastic Surgery to Improve Aesthetics in Patients with Altered Passive Eruption/Gummy Smile: A Case Series Study. International Journal of Dentistry. 2012.

24. Dharsiyani K, Bhongade ML, Bajaj P, Zanwar K, Dhote R. Esthetic Concern Due to Altered Passive Eruption Treatment by Periodontal Surgical Approach : A Case Series. JDMIMSU. Vol. 9 No. 2, 2014.

25. Kao R, Dault S, Frangadakis K, Salehieh JJ. Esthetic crown lengthening: appropriate diagnosis for achieving gingival balance. J Calif Dent Assoc. 2008;Mar; 36(3):187-91.

26. Jorgensen, MG., Nowzari, H. Aesthetic crown lengthening. Periodontology 2000. 2001. 27(1):45-58.

27. Garber, DA., Salama, MA., Salama, H. Immediate total root replacement in the external root resorption case - World Dentistry, 2000. 